\title{
Role of integrated use of nitrogen fertilizer sources in improving seed quality of canola (Brassica napus $\mathbf{L}$.)
}

\author{
Ayman El Sabagh*1, Abd Elhamid Omar ${ }^{1}$, Celaleddin Barutçular ${ }^{2}$, Hirofumi Saneoka ${ }^{3}$ \\ ${ }^{1}$ Department of Agronomy, Faculty of Agriulture, Kafrelsheikh University, Kafrelsheikh, Egypt \\ ${ }^{2}$ Department of Field Crops, Faculty of Agriculture, University of Cukurova, 01330 Adana, Turkey \\ ${ }^{3}$ Laboratory of plant nutritional physiology, Graduate School of Biosphere Science, Hiroshima University, Hiroshima, Japan

\section{A R T I C L E I N F O} \\ A B S T R A C T
}

\section{Article history:}

Received 12 August 2015

Accepted 10 January 2016

Available online, ISSN: 2148-127X

\section{Keywords: \\ Bio-fertilizers \\ Canola \\ Compost \\ Oil quality \\ $\mathrm{N}$-fertilizer \\ Protein}

"Corresponding Author:

E-mail: aymanelsabagh@gmail.com
It is necessary for developing strategies of integrated fertilization for crops to maximize production of crops and reducing the risk of pollution from chemical fertilizers. Therefore, the objectives of this study to evaluate the impact of bio-organic, chemical nitrogen on seed quality of canola. A study was conducted for two consecutive years (2005 to 2006) at the Farm of Faculty of Agriculture, Kafr El-Sheikh University, Egypt. Bio fertilizer (control and bio-fertilizer), compost (control, 6, 12 and 18 ton ha-1) and chemical nitrogen (control, 36, 72 and $108 \mathrm{~kg} \mathrm{~N}$ ha-1). The result indicated that, biofertilizer was significantly effects on protein $\%$ and iodine value except oil percent was decreased. On the other hand, the Maximum values oil and protein were recorded by using compost fertilizer at $\left(18\right.$ ton $\left.\mathrm{ha}^{-1}\right)$. In respect to chemical fertilizer, adding nitrogen affected significantly on protein $\%$ and the maximum value was obtained at (108 $\left.\mathrm{N} \mathrm{ha}^{-1}\right)$ while, oil percent and iodine value were decreased. Interestingly, it is clear that from results that cultivar belongs to canola (LEAR that contains < $2 \%$ erucic acid) and a nitrogen source has almost slight effect on oil physical properties. Totally, the interaction among treatments application compost (6ton $\left.\mathrm{ha}^{-1}\right)$ and $\left(72 \mathrm{~N} \mathrm{~kg} \mathrm{ha}^{-1}\right)$ with combined biofertilizer was achieved suitable oil percent and could be improve canola seed yield and quality and environment would have a better condition.

\section{Introduction}

Presently, Egypt is being faced by a problem arising from the shortage in local production of edible oils in compassion with the increased level of their consumption. This wide gap between the production and consumption of edible oils reached about 90\% (FAO Statistic Yearbook 2010).Therefore, there is an urgent need to agricultural expansion in new and marginal areas out of Nile Valley and Delta for increasing the production of oil crops. It is important to introduce a new winter oil crops able to grow under harsh environmental conditions prevailing in these areas such as canola (Emam, 2014). According to country`s necessity and Limited resources of water, that can be considered promising point to provide parts of required oil. Special specifications of Canola and Compatibility with different climate conditions, made it so important and considered as a promising point to provide parts of country`s required edible oil (Baj et al., 2013).

Canola (Brassica napus L.) is a member of the Brassicaceae and has become one of the most important sources of vegetable oil in the world. Its oil also has potentially developed in the bio-diesel market. In addition to oil production, the leaves and stems of canola provide high quality fodder (Dahmardeh, 2013).Canola oilseed species currently hold the third position among oilseed crops and are an important source of vegetable oil (Ashraf and McNeilly, 2004). Canola has the lowest saturated fat content among vegetable oils and thus presents an increasing demand for diet-conscious consumers (Grombacher and Nelson, 1992). Erucic acid and glucosinolate are considered toxic for both human and animals' health, in addition to its bitter taste (Muhammad et al., 1991). Safe limits for these compounds have been described as less than $2 \%$ of erucic acid in oil (Grombacher and Nelson, 1992).

Improved varieties of canola or hybrids are capable of higher yields when grown under optimum fertility level. Nitrogen increases yield by influencing different growth parameters (Taylor et al., 1991). Which is worth to be considered in relation to its role in affecting quality and quantity. Compared to cereals, it has a higher critical N demand (Colnenne et al., 1998). Physiological efficiency of nitrogen in fall canola can reduce environmental pollution and enhance the economic income. To improve 
this efficiency and reduce environmental pollution, several fertilizer integrated management strategies have been developed (Rathk et al, 2006). Therefore, the compost application allowed good yields and quality, even without an additional mineral fertilization. Also, its application could improve the soil organic matter and minimize the problems related to waste disposal and to reduce the environmental pollution caused by a excessive application of mineral fertilizers (Maiorana, et al., 2005). Additionally, using of bio-fertilizers, it's effectively helps to improve farming. Bio-fertilizer is increasing Gibberellin level and Gibberellin also increases root growth. By increasing the root, the plant's power to uptake nitrogen and nutrients will increase and Increase the permeability of the soil, increase soil water holding capacity, soil nutrients and Leads to an increase in nutrient uptake by plants (Hamidi et al., 2015).Therefore, this study is aimed at reducing the use chemical fertilizers to reduce environmental pollution and determining the optimum level of fertilizer to improve the seed quality of canola under North Delta conditions in Egypt.

\section{Materials and Methods}

\section{Plant Material and Culture Conditions}

The study was conducted at the farm of the Faculty of Agriculture, Kafr El-Sheikh University for two consecutive years (2004/2005 and 2005/2006). Treatments of experiment were arranged in a strip- spilt plot design with four replications. The horizontal plots are control and with Bio-fertilizer. The vertical plots are compost, control, 6, 12 and 18 ton $\mathrm{ha}^{-1}$. Sub vertical plots are nitrogen fertilizer, control, 36, 72 and $108 \mathrm{~kg} \mathrm{~N} \mathrm{ha}^{-1}$. Seed of canola CV. Serw4 was obtained from Agriculture Research Center, Egypt. The samples were prepared and analyzed having soil, $\mathrm{pH} 8.25$, Organic matter $1.55 \%$ and available nitrogen $22 \mathrm{ppm}$. Each plot area was "10.5" $\mathrm{m}^{2}$ and each plot included 6 rows $(3.5 \mathrm{~m}$ long and $50 \mathrm{~cm}$ apart) with $20 \mathrm{~cm}$ between hills. Compost is manufactured using rice hay $(60 \%)$, farmyard manure $(25 \%)$, poultry manure $(10 \%)$ and fertile soil $(5 \%)$. Nitrogen fertilizers in the form of ammonium sulfate $(20.5 \% \mathrm{~N})$ was applied in two doses, phosphorus and potassium fertilizers were added before sowing at the rate of 200 and $100 \mathrm{~kg} \mathrm{ha}^{-1}$ of calcium supper phosphate $(15.5$ $\left.\% \mathrm{P}_{2} \mathrm{O}_{5}\right)$ and Potassium sulphate $\left(48 \% \mathrm{~K}_{2} \mathrm{O}\right)$, respectively.

\section{Plant Sampling and Measurements}

Crude oil content: Oil content of seed was estimated according to (AOCS, 1980) using Soxhelt apparatus and petroleum ether $\left(40-60^{\circ} \mathrm{C}\right)$ as a solvent.

Protein content: Total nitrogen determined by Kjeldahl method according to (AOAC, 1980) The crude protein was calculated by multiplying nitrogen percentage by converting factor [6.25] (Robinson, 1975).

Iodine number: The iodine number was determined according to the (AOAC, 1975) using Hanus method, The iodine value was calculated in grams of iodine absorbed by 100 grams oil according to the following equation:
Iodine number $=\frac{(\mathrm{a}-\mathrm{b}) \times \mathrm{N} \times 126.9 \times 100}{\mathrm{~W} \times 100}$

Where:

$\mathrm{a}=$ Titration volume of sodium thiosulphate solution in $\mathrm{ml}$ required for blank.

$\mathrm{b}=$ Titration volume of sodium thiosulphate solution in $\mathrm{ml}$ required for sample.

$\mathrm{N}=$ Normality of sodium thiosulphate solution.

$\mathrm{W}=\mathrm{Weight}$ of oil sample in gram.

Acid value: Acid value was determined according to (IUPAC, 1987). The acid value was calculated according to the following equation:

$$
\text { Acid value }=\frac{\mathrm{V} \times \mathrm{N} \times 56.1}{\mathrm{~W}}
$$

Where:

$\mathrm{V}=$ Volume in $\mathrm{ml}$ of $\mathrm{KoH}$ solution in $\mathrm{ml}$ required for neutralization.

$\mathrm{N}=$ Normality of $\mathrm{KoH}$.

$\mathrm{W}=$ Weight of oil sample in grams

Free fatty ccid (FFA): Free fatty acids of the extracted lipids were determined by titration methods of (AOAC, 1980).

Erucic acid: Was determined by using Gas Liquid Chromatography; the methyl esters were prepared according to Stahl (Stahl, 1967) using Benzene: Methanol: Sulphuric acid (conc.) as a ratio of 10:86:4).

\section{Statistical Analysis}

All data collected for both seasons were subjected to analysis of variance according to Gomez and Gomez ,1984).and treatment means were compared using Duncun Multiple Range Test (Duncan, 1955).All statistical analysis performed using analysis of variance technique by "MSTAT-C" computer software package 1990.

\section{Results and Discussion}

\section{Oil Content}

Results showed bio-fertilizer treatment was not significant effects on seed oil content (Table 1). These results might be due to the effect of organic acids which produced by the microorganisms of bio-fertilizers, which led to enhance the availability of fertilizer. Sharma et al., (1997) who reported some negative correlation between oil and protein content under the Bio-fertilizer. In our study, the increment of compost fertilizer affected significantly the oil content of canola (Table1).These results agree with those obtained by Haikclet al. (2000). According to the results, increasing rate of nitrogen decreased oil content and application of $36 \mathrm{~kg} \mathrm{~N} \mathrm{ha}^{-1}$ introduced the highest seed oil content (Table 1). These results might be due to the negative correlation between oil and protein content, there by inhibiting oil formation and consequently increase protein content. Similar results were also reported by El-Kholyet al. (2004). Patil and 
Bhargava (1989) reported similar results with $\mathrm{N}$ in respect of oil and protein contents of Brassica juncea. Several reasons have been given by different researchers for the decrease in oil content with increasing $\mathrm{N}$ rates. For example, Kutcher et al., (2005) stated that it might be due to the dilution effect of increased seed yield with increased $\mathrm{N}$ fertilization and the inverse relationship between protein and oil content. Jackson (2000) believed that $\mathrm{N}$ delays plant maturity which results in poor seed filling and greater proportion of green seed.

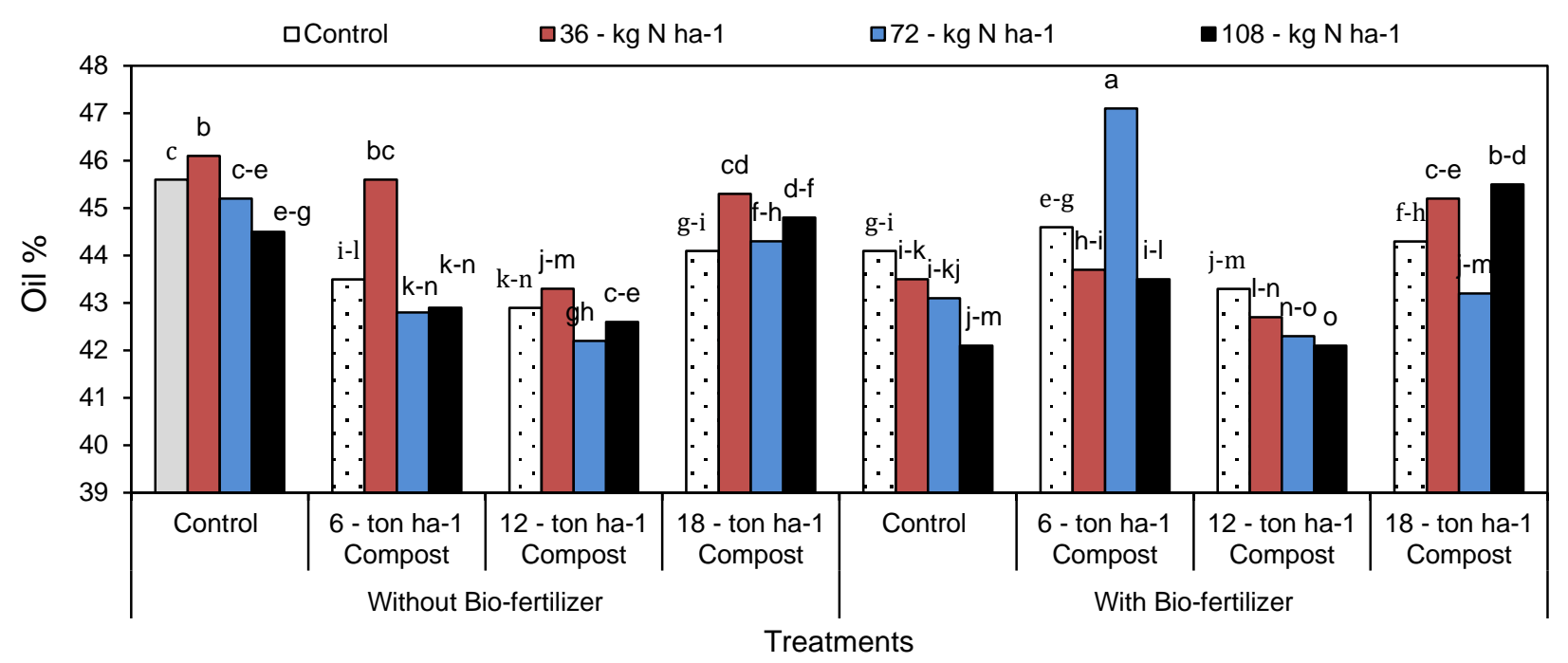

Figure 1 Means of oil $\%$ as influenced by the interaction among bio-fertilizer, compost fertilizer and nitrogen level (Means followed by the same letters in each trait are not significantly different at $5 \%$ level, according to Duncan's test).

Concerning the interacted factors under study on oil percent in canola seed, data in (Figure 1) showed that the oil content of canola seed improved significantly by application compost $\left(6 \text { ton }^{-1}\right)^{-1}$ and $\left(72 \mathrm{~N} \mathrm{~kg} \mathrm{ha}^{-1}\right)$ with combined bio- fertilizer and achieved maximum oil percent (Figure 1). It is interesting to note that, application compost $\left(6\right.$ ton $\left.^{-1} \mathrm{ha}^{-1}\right)$ and $\left(72 \mathrm{~N} \mathrm{~kg} \mathrm{ha}^{-1}\right)$ with combined bio- fertilizer showed superiority treatment and can be more effective and beneficial to improve oil content. Generally, inoculation with bio-fertilizer more positive result and could be benefits and more effective with adding compost together.

\section{Protein Content}

Obtained results indicate that, Seed protein content was significantly influenced by by bio-fertilizer (Table 1). Similar results were reported by (Farag, 2003).Application of compost had a significant effect on protein percentage and application of 18 ton $\mathrm{ha}^{-1}$ gave the highest protein percentage (Table 1). These results might be due to organic matter improve soil structure, beside its role in increasing water holding capacity and exchange capacity. It also decrease susceptibility to erosion and led to an increase in the availability of nutrient and increase the activity of macro and micro elements (Haikleet al., 2000). It was clear that, the results revealed that protein percentage increased with increasing nitrogen levels and $108 \mathrm{~kg} \mathrm{ha}^{-1}$ introduced the maximum seed protein content. The increase might be due to increasing availability of $\mathrm{N}$, causing accelerated photosynthetic rate and thus leading to the production of more carbohydrates and more synthesis of amino acid than lipids, there by inhibiting oil formation and consequently increase protein content.
Similar results were also reported by (El-Kholyet al., 2004). As a result, the high protein content at high level of $\mathrm{N}$ may be due to the negative correlation between oil content and protein content (Hao et al., 2004). Oil content decreased with increase in $\mathrm{N}$ level in this study. The physiological reason for the negative correlation may be that the carbohydrate content of protein is lower than that of oils (Lambers and Poorter, 1992). Increased N supply intensifies the synthesis of protein at the expense of fatty acid synthesis and thus reducing the oil content of the seed (Rathke et al., 2005).

\section{Iodine Value}

The data in (Table 1) indicated that the control treatment produced the higher value of iodine value with comparison the bio-fertilizer treatments. On the other hand, iodine value was not significantly affected by compost fertilizer application under this study (Table 1). The results (Table 1) showed that the effect of nitrogen level on iodine value was significant. While control treatment produced the higher value of iodine value (Table 1).Nitrogen application increased the oil-quality index (iodine number) in rape (Narang et al., 1993). The iodine value is oil properties and related to the oil quality genetics more than the environmental effects during plant growth in the field (El-Nakhlawy and Bakhashwain, 2009) . This may be attributed to late flowering, which affected fatty acids synthesis and lowered both iodine value (Saleh, 1997).

Table 1 . Means of oil \%, protein \%, iodine value, acid value, free fatty acid and Erucic acid as as affected by different nitrogen sources and rates. 
Table 1 Means of oil \%, protein \%, iodine value, acid value and free fatty acid as influenced by different nitrogen sources and rates

\begin{tabular}{|c|c|c|c|c|c|}
\hline Factor & Oil, \% & Protein, $\%$ & Iodine value & Acid value & Free fatty acid \\
\hline \multicolumn{6}{|c|}{ Biofertilizer (A) } \\
\hline Without inoculation & $44.8 \mathrm{a}$ & $21.7 \mathrm{~b}$ & $121.5 \mathrm{a}$ & 0.67 & 0.27 \\
\hline Inoculation(Azotobacter) & $43.8 \mathrm{~b}$ & $22.3 \mathrm{a}$ & $121.1 \mathrm{~b}$ & 0.68 & 0.28 \\
\hline F. test & $* *$ & $* *$ & $*$ & N.S & N.S \\
\hline \multicolumn{6}{|c|}{ Compost rate (ton ha- $\left.{ }^{1}\right)(\mathrm{B})$} \\
\hline Control & $44.3 b$ & $21.2 \mathrm{~d}$ & 121.5 & $0.68 \mathrm{ab}$ & $0.27 b$ \\
\hline 6 & $44.2 \mathrm{~b}$ & $21.9 \mathrm{c}$ & 121.1 & $0.62 b$ & $0.27 \mathrm{ab}$ \\
\hline 12 & $43.0 \mathrm{c}$ & $22.3 b$ & 121.2 & $0.69 \mathrm{ab}$ & $0.28 \mathrm{ab}$ \\
\hline 18 & $44.6 \mathrm{a}$ & $22.7 \mathrm{a}$ & 121.1 & $0.70 \mathrm{a}$ & $0.282 \mathrm{a}$ \\
\hline F. test & $* *$ & $* *$ & N.S & $* *$ & $* *$ \\
\hline \multicolumn{6}{|c|}{ N. level $\left(\mathrm{kg} \mathrm{N} \mathrm{ha-}^{-1}\right)(\mathrm{C})$} \\
\hline Control & $44.1 \mathrm{~b}$ & $21.1 \mathrm{~d}$ & $122.5 \mathrm{a}$ & $0.64 b$ & $0.25 b$ \\
\hline 36 & $44.4 \mathrm{a}$ & $21.8 \mathrm{c}$ & $121.7 b$ & $0.67 \mathrm{ab}$ & $0.28 \mathrm{ab}$ \\
\hline 72 & $44.2 b$ & $22.4 b$ & $120.8 \mathrm{c}$ & $0.67 \mathrm{ab}$ & $0.29 \mathrm{ab}$ \\
\hline 108 & $43.5 c$ & $22.8 \mathrm{a}$ & $119.9 d$ & $0.689 a$ & $0.287 \mathrm{a}$ \\
\hline F. test & $* *$ & $* *$ & $* *$ & $* *$ & $* *$ \\
\hline \multicolumn{6}{|c|}{ Interaction } \\
\hline$A * B$ & $* *$ & $* *$ & N. S & N.S & N. S \\
\hline $\mathrm{A} * \mathrm{C}$ & $* *$ & N. S & N. S & N. S & N. S \\
\hline $\mathrm{B} * \mathrm{C}$ & $* *$ & $* *$ & N. S & N. S & N. S \\
\hline $\mathrm{A} * \mathrm{~B} * \mathrm{C}$ & $* *$ & $* *$ & N. S & N. S & N. S \\
\hline
\end{tabular}

**: highly significant at the $1 \%$ level of probability .means within the same column of each factor followed by a common latter is not significantly different at $5 \%$ level, by DMRT

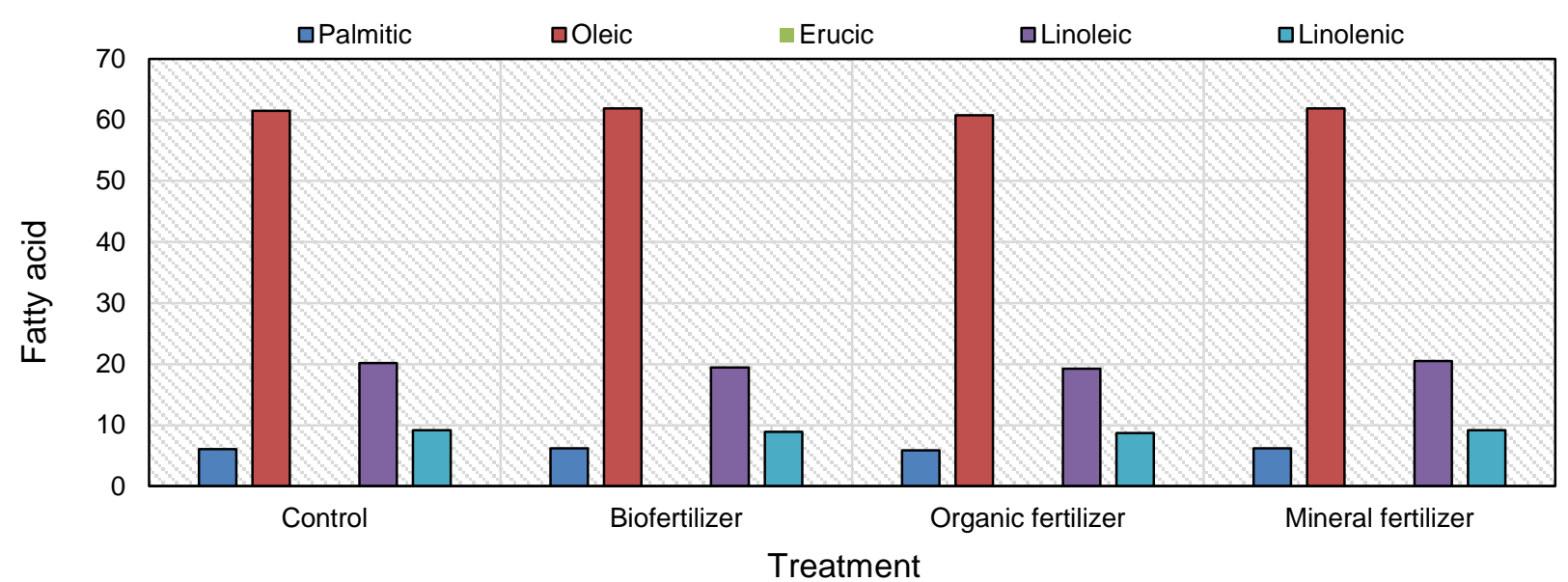

Figure 2 Means of Fatty acid composition (\%) as influenced by the bio-fertilizer, compost fertilizer and nitrogen level

\section{Acid Value}

In our study, Acid value was not significant influenced by bio-fertilizer treatments (Table 1). Application of compost had a significant effect on acid value and application of 18 ton ha $^{-1}$ gave the highest acid value (Table 1).It was clear that, the results revealed that acid value increased with increasing nitrogen levels and $108 \mathrm{~kg} \mathrm{ha}^{-1}$ introduced the maximum seed acid value (Table 1).The increase is beneficial as it increases oil stability (Downey and Rimmer, 1993). Generally, It can be observed from the obtained results that nitrogen fertilization sources has almost slight effect on oil physical properties.

\section{Free Fatty Acids}

Free fatty acids were not significantly influenced by bio-fertilization treatments of this study (Table 1). While, compost fertilizer application was significant effects on free fatty acids by increasing compost rate (Table 1). Concerning, nitrogen fertilizer application, it was significant effects on free fatty acids (Table 1).Generally, It can be observed from the obtained results that nitrogen fertilization sources has almost slight effect on oil physical properties.

\section{Erucic Acid}

It is clear that from data that cultivar belongs to canola (LEAR that contains $<2 \%$ erucic acid) (Figure 2). 
Obtained results indicate that, Erucic acid did not respond to nitrogen sources. These results agree with (Gao et al., 2009) who reported that there was no difference between the manure and control treatments. Ibrahim et al. (1989) observed that no significant effect on oil fatty acid composition of $\mathrm{N}$ fertilizer applications. Holmes and Bennett, (1979) commented that, the fatty acid composition of rape oil is mainly under genetic control, but can be modified to some extent by $\mathrm{N}$ nutrition.

\section{Conclusion}

We conclude that, application bio fertilizer promoted protein percent but oil percent was not significantly influenced by bio fertilizer. As well as, protein \% was significantly influenced by nitrogen fertilizer while, oil percent was not significantly influenced by nitrogen fertilizer. In respect to organic fertilizer, application of compost showed significant effects on protein and oil percent. Interestingly, it is clear that from results that cultivar belongs to canola (LEAR that contains $<2 \%$ erucic acid). In this concern, nitrogen fertilization sources has almost slight effect on oil physical properties, Totally, application of compost (12 ton ha-1) and chemical nitrogen (72 $\mathrm{N}$ kg ha-1) combining with bio-fertilizer could be recommended to avoid negative effects of high nitrogen levels and it is considered one of the efficient ways to improve production and quality of canola and environment would have a better condition.

\section{Acknowledgements}

Sincere thanks to all staff members in Agronomy department, faculty of agriculture, Kafrelshikh University, Egypt.

\section{References}

AOAC.1980. Association of official agriculture chemists "official methods of analysis" $13^{\text {th }}$ Ed., Washington, DC, USA.

AOAC. 1975. Official methods of analysis of the association of official analytical chemistry, 12th Edition DC. T. McNeilly

Ashraf M, McNeilly T. 2004.Salinity tolerance in some brassica oilseed. Critical Reviews in Plant Sciences, London 23(2): 157174.

Baj JBB, Nasri M, Zarghami R. 2013. Yield Evaluation and components of Canola (Hyola-401) species in different densities of seeds Influenced by chemical, Farmyard manure, Vermicompost and Biological fertilizers.International Journal of Agriculture and Crop Sciences, 6-(6)305-312.

Colnenne C, Meynard JM, Reau R, Justes E, Merrien A. 1998.Determination of a critical nitrogen dilution curve for winter oilseed rape. Ann Bot. 81(2):311-317.

Dahmardeh M. 2013.Effect of Different Bio Fertilizers on Growth and Yield of Canola (Brassica napus L) var RGS 003. Journal of Agricultural Science; 5(9):143-147.

Downey RK, Rimmer SR. 1993.Agronomic improvement in oil seed brassicas. Adv. Agr. 50: 1-66.

Duncan BD. 1955. Multiple range and multiple F. Test. Biometrics, II: $1-42$.

El-Kholy MH.2004. Physiological and chemical studies on some rape seed varietes grown under different levels of nitrogen fertilization. Egypt. J. Biotechnol. 17 (7): 486- 498.
El-Nakhlawy FS, Bakhashwain AA. 2009. Performance of Canola (Brassica napas L.) Seed Yield, Yield Components and Seed Quality under the Effects of Four Genotypes and Nitrogen Fertilizer Rates. JKAU: Met., Env. \& Arid Land Agric. Sci., Vol. 20, No. 2, pp: 33-47.

Emam SM.2014. Response of (Brassica napus L.) genotypes to nitrogen fertilization in a newly-reclaimed soil. Acta Advances in Agricultural Sciences, 2 (11):45-57.

Farag AMH. 2003. Response of wheat plants to some treatments of soil leveling and fertilization wheat with both nitrogen and biological fertilizers. Ph.D. Thesis, Fac. Agric. Mansoura Univ., Egypt.

FAOSTAT .2010.http//faostat.fao.org/. (Accessed February 26, 2010

Gao J, Pedersen JA. 2009. Sorption of sulfonamide antimicrobial agents to humic acid-clay complexes. J. Environ. Qual. 39: 228-235.

Grombachr A. 1992.Nelson, L. Canola production. Lincoln: University of Nebraska.

Haikel MA, Samira MA, Hussein. El-Melegy AM. 2000. Effect of organic and mineral nitrogen on maize and its residual effect on wheat as a successive crop in sand soil under new irrigation systems. J. Agric. Sci. Mansoura Univ. 25 (7): 3803- 3816.

Hamidi M, Nasri M, Hanifepoor M. 2015.Comparison of chemical and biological fertilizers on yield and yield components of RGS canola seed in different seed densities. International Journal of Agriculture and Crop Sciences ,8(3):427-432.

Hao X, Chang C, Travis GJ.2004.Short communication: effect of long-term cattle manure apllication on relations between nitrogen and oil content in canola seed. J. Plant Nutr. Soil Sci. 167(2):214-215.

Holmes MRJ, Bennett D. 1979.Effect ofnitrogen fertilizer on the fatty acid composition of oil from low erucic acid rape varieties. J. Sci. Food Agric. 30: 264-26.

Ibrahim AF, Abusteit EO, El Metwally EMA. 1989. Response of rapeseed (Brassica napus L.) growth, yield, oil content and its fatty acids to nitrogen rates and application times. J. Agron. Crop Sci. 162:107-112.

IUPAC.1987. Standard Method 2.301, preparation of fatty acid methyl esters, in Standard Methods for oxford, Blackwell.

Jackson GD. 2000.Effects of nitrogen and sulfur on canola yield and nutrient uptake.Agron. J. 92(4): 644-649.

Kutcher HR, Malhi SS, Gill KS. 2005. Topography and management of nitrogen and fungicide affects diseases and productivity of canola. Agron. J. 97(2):533-541.

Lambers H, Poorter H.1992.Inherent variation in growth rate between higher plants: a search for physiological causes and ecological consequences. Adv. Ecol. Res. 23(1):187-261.

Maiorana M, Charfeddine M, Montemurro F, Vonella AV. 2005.Reduction of agronomic inputs in sunflower (Helianthus annuus L.). HELIA 28(42): 133-146.

Mekki BEB. 1990. Effect of fertelization with some macro elements, water supply and other cultural treatments on oilseed rape (Brassica napus L.). ph. D. thesis, Fac. of Agric. Cairo Univ., Egypt.

Muhammad S, Khalil IA, Khan S. 1991.Fatty acid composition of rape and mustard oilseed cultivars.Khyber Science Journal, Peshawar 4(1): 29-36.

Narang RS, Mahal SS, Gill MS. 1993. Effect of phosphorus and sulphur on growth and yield of toria (Brassica campestris subsp. oleiferavartoria).Indian J. Agron. 38: 593-597.

Patil BN, Bhargava SC. 1987. Seed quality studies in rapeseed mustard in relation to nitrogen nutrition. Ann. PI. Physiol. 1(1): 81-87.

Rathke GW, Christen O, Diepenbrock W. 2005. Effects of nitrogen source and rate on productivity and quality of winter oilseed rape (Brassica napus L.) grown in different crop rotations. Field Crops Res. 94(2-3):103-113.

Rathke GW, Christen O, Diepenbrock W. 2006. Welchen Beitrag leisten Vorfrucht und Stickstoffdu ngung fu rden Ertrag von Winterraps? (with English summary). UFOP-Schriften Heft 29, Ol- und Proteinpflanzen, OIL 2005: 149-156. 
Saleh. Sh.Z.1997. Effect of fertilizers and pesticides on the chemical constituents of some oil seeds. M.Sc. Thesis, Fac. Of Agric. Mansoura Univ.

Sharma A, Kraus N, McGee T, Nicol T. 1997. Developmental changes in P1 \& N1 auditory responses elicited by consonantvowel syllables. Clin. Neurophysiol. 104: 540-545.
Stahl E. 1967. Thin layer chromatography.A Laboratory Handbook. Ed. Springer Verlag, Berlin pp: 359 Heidel Berg, New York.

Taylor AJ, Smith CJ, Witson IB. 1991.Effect of irrigation and nitrogen fertilizer on yield, oil content, nitrogen accumulation and water use of canola (Brassica napus L.). Ferti. Res. 29: 249-260. 